\title{
ХРОНИКА
}

\section{К 100-ЛЕТИЮ ВЫХОДА В СВЕТ ПЕРВОГО ВЫПУСКА ТРУДОВ КАРАДАГСКОЙ НАУЧНОЙ СТАНЦИИ ИМЕНИ Т.И. ВЯЗЕМСКОГО}

В 2017 г. является дважды юбилейным: исполняется 100 лет с момента выхода в свет первого выпуска Трудов Карадагской научной станции им. Т.И. Вяземского и 160 лет со дня рождения основателя станции Т.И. Вяземского. Главным научным событием в истории станции стал выход первого выпуска Трудов Карадагской научной станции имени Т.И. Вяземского. Этим знаменательным событием завершился десятилетний (1907-1917) период становления станции (Михаленок, 2016). Ретроспективно возвращаясь к событиям того времени, 1917 г., можно узнать, как заведующий Карадагской научной станцией А.Ф. Слудский - ученик академика А.П. Павлова, был обеспокоен ситуацией с печатаньем Трудов станции. В апреле А.Ф. Слудский послал И.А. Каблукову «последнюю корректуру, и надеялся в мае получить готовый том» (Михаленок, 2016, с. 17). Долгое время А.Ф. Слудскому пришлось ждать добрых вестей, которые он наконец, получил от А.П. Павлова. В письме к А.П. Павлову от 09.10.1917 г. А.Ф. Слудский отмечал: «Ваши добрые вести меня просто потрясли... И из всех вестей, конечно, выше и ценнее всех - известие о выходе выпуска Трудов. Вы не можете представить себе, как я боялся за этот выпуск! Я ждал всего худшего: еще весной я слышал в типографии от заведующего типографией, что, вероятно, придется типографию закрыть. Если бы наш выпуск не вышел, то это был бы такой удар, последствия которого трудно учесть. Поэтому известие о выходе выпуска для меня звучит как самая радостная весть о спасении близкого человека... Только с этого момента существование Станции получает некоторый аргумент, который... имеет абсолютную ценность, как первый выявившийся результат десятилетних усилий по созданию станции. И я счастлив сейчас за Терентия Ивановича. Это начало его оправдания на суде истории» (Михаленок, 2016, с. 21).

А.Ф. Слудский наладил на станции научно-исследовательскую работу и издательскую деятельность (Стародубцева, 2004). Станция получает широкую известность, на ней работает ряд видных исследователей и в 1917 г. Станция издает первый выпуск собственного органа: Труды Карадагской научной Станции (Слудский, 2004). Первый выпуск Трудов станции был издан в Москве под редакцией председателя Общества содействия успехам опытных наук и их практических применений имени Х.С. Леденцова, заслуженного профессора Московского университета И.А. Каблукова и заведующего Станцией А.Ф. Слудского. Станция стала более известна в научном мире именно благодаря первому выпуску Трудов (Михаленок, 2016). Это издание пригодилось для книгообмена с другими исследовательскими организациями (Любина, 2017).

В предисловии к выпуску Трудов, бережно хранящемся на протяжении века в библиотеке станции, А.Ф. Слудский писал: «Приступая к печатанью первого выпуска Трудов Карадагской Научной Станции имени Т.И. Вяземского, осуществляя ту мечту, с которой жил и с которой сошел в могилу, не дождавшись ее осуществления, незабвенный основатель Станции, я обращаюсь ко всем, кому дорого развитие и процветание научной работы в России, с просьбой благосклонно принять эту книжку» 
(Слудский, 1917). И далее по тексту: «Выпуская эту книжку, я обращаюсь от имени Ова Х.С. Леденцова ко всем учреждениям, обществам и отдельным лицам, работающим по отдельным отраслям естествознания, с просьбой принять Станцию, как новую единицу в общей семье научных учреждений России, посильно содействовать ее процветанию и развитию и присылать в библиотеку Станции свои ученые труды» (Слудский, 1917).

Содержание первого выпуска Трудов включало мемориальную часть: некролог о Т.И. Вяземском, статью «Терентий Иванович Вяземский, как основатель Карадагской Научной Станции», написанные А.Ф. Слудским. Здесь же был помещен доклад С.С. Крыма, прочитанный им на заседании Феодосийского Отделения КрымскоКавказского горного клуба 12 сентября 1916 года «Терентий Иванович Вяземский. Встречи и воспоминания». Приват-доцент Московского университета А.И. Бачинский посвятил свою статью научно-литературной деятельности Т.И. Вяземского.

В первом выпуске Трудов отражены результаты геологических исследований, проведенных А.Ф. Слудским на Карадаге - помещен доклад «Новые данные по геологии и палеонтологии Карадага (Статья 3-я о Карадаге), прочитанный им на заседании Императорского Московского Общества Испытателей Природы 17 сентября 1915 года.

По результатам зоологических работ, проведенных помощником А.Ф. Слудского В. Вучетичем летом 1915 г., приведены списки дневных и ночных бабочек, а также перепончатокрылых насекомых окрестностей Карадагской Научной Станции.

Примечательно, что профессор А. Остроумов, побывав в 1916 г. на Карадагской Научной Станции, обнаружил в планктонных пробах новую, ранее не описанную форму солнечников из рода Acanthocystis и предложил ее назвать в память основателя станции Т.И. Вяземского, что нашло отражение в его статье «О новом виде солнечников в морском планктоне (Acanthocystis Wiasemskii).

Ботаник Н.Ф. Слудский поместил в Трудах «Заметку о флоре Карадага», куда вошел список из 239 видов растений.

Приводится «Отчет о морских зоологических работах 1915-16 года» В. Вучетича со списком морских ловов у берегов Карадага. А.Ф. Слудский и В.Н. Вучетич также изучали морские течения у берегов Карадага. Помещен Отчет заведующего станцией за 1915 и 1916 гг.

Первый выпуск Трудов завершается разделом «Организация Карадагской Научной Станции имени Т.И. Вяземского», в котором под первым пунктом отражено основное назначение Станции: «Карадагская научная станция имени Т.И. Вяземского устраивается для содействия научным занятиям по различным отраслям естествознания (преимущественно по отделу биологии и геологии), их применения к задачам практики, а также для распространения научных сведений в пределах указанного цикла наук». Приводится Инструкция для заведующего Карадагской научной станцией, утвержденная Советом общества и Правила для работающих на Карадагской Научной Станции.

За долгую историю деятельности Карадагской Научной, а впоследствии биологической станции вышло 18 выпусков ее Трудов - непериодического издания, последний из которых относится к 1962 году. В 2016 г. как СМИ Российской Федерации зарегистрировано издание «Труды Карадагской научной станции им. Т.И. Вяземского - природного заповедника РАН» и вышло 3 выпуска названных трудов, что является продолжением славных традиций Карадагской научной станции, заложенных еще ее основателями (рис. 1). 

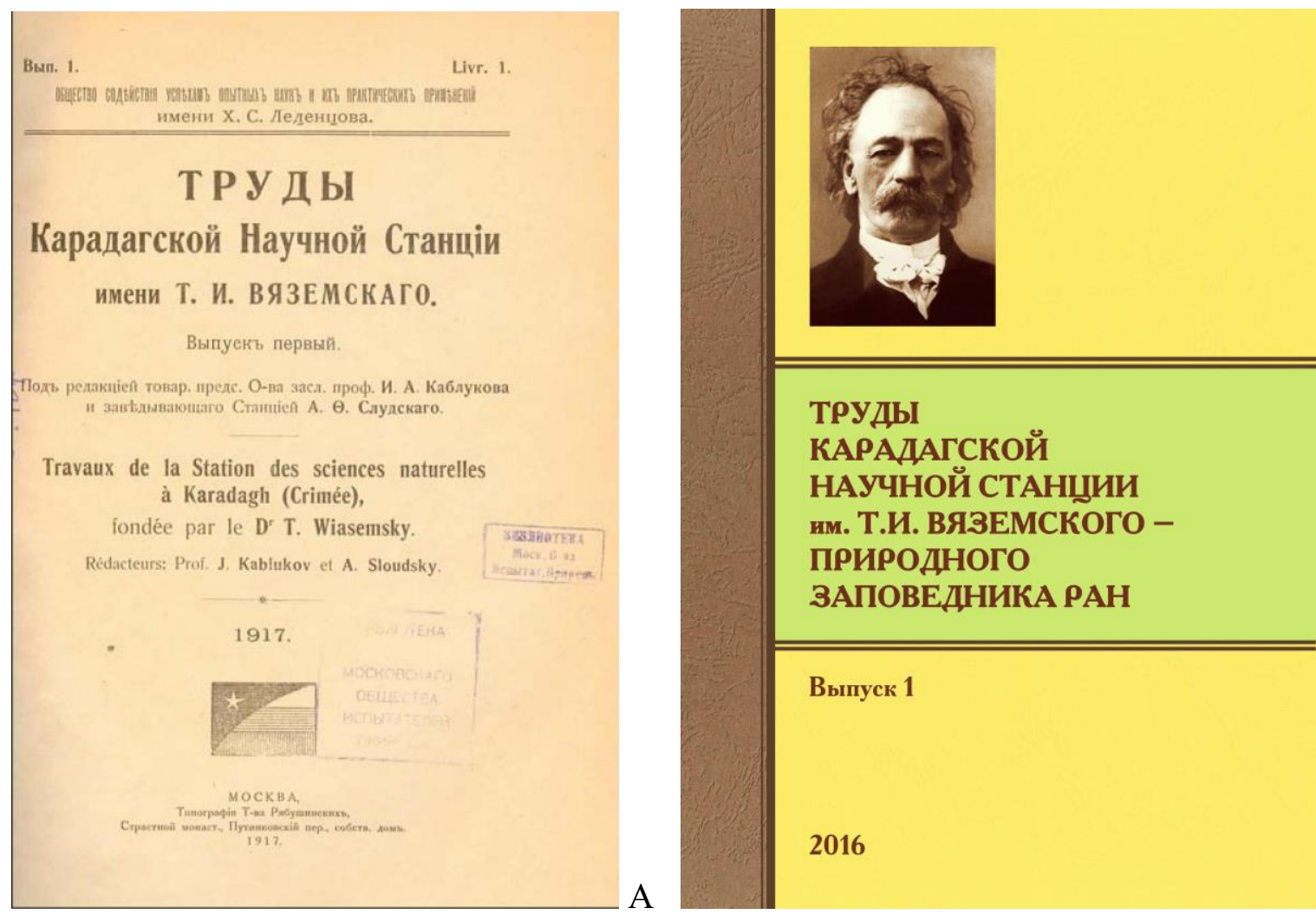

Выпуск 1

2016

Рис. 1. А - титульный лист 1-го выпуска журнала «Труды Карадагской научной станции» (1917 г.), Б - обложка журнала «Труды Карадагской научной станции им. Т.И. Вяземского - природного заповедника РАН» (2016 г.)

\section{Список литературы}

1. Любина Г.И. А.Ф. Слудский - первый директор Карадагской научной станции // Природа. - 2017. - № 3. - С. 69-79.

2. Михаленок Д.К. А.Ф. Слудский и Карадагская научная станция имени Т.И. Вяземского в 1917 году // Труды Карадагской научной станции им. Т.И. Вяземского - природного заповедника РАН. - 2016. - Вып. 2. - С. 2-30.

3. Труды Карадагской Научной Станции имени Т.И. Вяземского. - М.: 1917. - 112 с.

4. Слудский А.Ф. От заведующего станцией // Труды Карадагской научной станции имени Т.И. Вяземского. - М.: 1917 г. - С. 4.

5. Слудский А.Ф. Карадагская научная станция // Карадаг. История, геология, ботаника, зоология. Сборник научных трудов, посвященный 90-летию Карадагской научной станции и 25-летию Карадагского природного заповедника НАН Украины. Книга 1-я. - Симферополь: СОНАТ. - 2004. - С. 22-27.

6. Стародубиева И.А. Слудский Александр Федорович // Павловская геологическая школа. - М.: Наука, 2004. - С. 123-126.

Н.С. Костенко 